G E N E R A L T O P O L O G 



\section{GENERAL TOPOLOGY}

WOLFGANG FRANZ

Professor of Mathematics

University of Frankfurt-on-Main

Translated from the German by

LEO F. BORON

The Pennsylvania State University

With the assistance of

ROBERT L. BLEFKo

ROBERT C. MOORE

SAMUel D. Shore

JAMes L. Sieber

The Pennsylvania State University

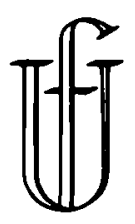

FREDERICK UNGAR PUBLISHING CO. NEW YORK 
Translated from the second German edition of Topologie: I, Allgemeine Topologie

By arrangement with Walter de Gruyter \& Co., Berlin

Copyright $\odot 1965$ by Frederick Ungar Publishing Co., Inc.

Printed in the United States of America

Library of Congress Catalog Card No. 65-28047 


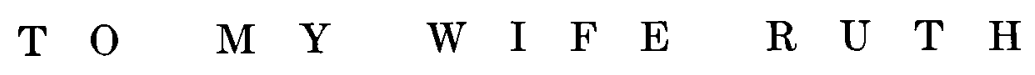


